\title{
A framework for success criteria for mine closure, reclamation and post-mining regeneration
}

\author{
N.J. Coppin Independent consultant, formerly Wardell Armstrong International, UK
}

\begin{abstract}
What are the appropriate criteria for judging when a mine closure or reclamation process has been successful? This is a continuing problem for the mining industry and regulators; it also seems to be a very difficult one to nail down. There are many guidelines and frameworks for mine closure and reclamation, but the great majority are based on processes - the 'means' rather than the 'ends', which are outcomes such as future use, performance and function.

Success is often judged in the very short term, or is judged post-facto, with hindsight. Criteria, where they are set, tend to be considered from a single aspect or narrow perspective, such as ecological conditions. This paper attempts to take a fresh look across a whole range of aspects and disciplines to set out a possible framework for setting success criteria, based on objectives and outcomes rather than processes. It does not attempt to review all the criteria and methods published previously, and it does not present a set of criteria that can be used off the shelf. It is, as the title suggests, a suggested framework that can be developed, improved and built on.
\end{abstract}

This paper will consider a number of perspectives:

- The objectives and outcomes required, in terms of afteruses, regeneration, etc., including hard and soft uses for economic and non-economic purposes.

- What the criteria, used to measure success against the objectives, are required for - judging an award, relinquishment of responsibility (liability) or sign-off of licence or permit conditions, release of bonds, etc.

- The timescale - from closure planning and design for closure, through life of mine, progressive reclamation and decommissioning, to active care and long-term passive care stages.

- Whether the closure and rehabilitation is part of a planned closure, with identified objectives and criteria, or is unplanned forced closure or dealing with abandoned legacy sites, where opportunist approaches may be more applicable.

- Risk assessment as an important aspect of setting meaningful closure criteria.

- The danger that 'criteria' can become 'targets', and the problems that so often occur with a target-based approach.

Finally, the paper sets out a framework for selecting and applying criteria, with a suggested outline of the available indicators and metrics that can be used to measure them, grouped under seven headings: ecological, geochemical, engineering/geotechnical, hydrological, economic, cultural and - last - social and community.

This paper does not attempt to present all the answers; the author's purpose is to raise questions and suggest an approach as the basis for discussion for the industry and regulators to take forward. 


\section{Introduction - why criteria are important}

Mining is only a temporary use of the land, and much has been written about the need for and approaches to mine closure, reclamation and post-mining regeneration. Within all this, the most important outcomes are generally considered to be:

- The removal of hazards, contamination, constraints, etc.

- Achieving a beneficial condition of and afteruses for land, including self-sustaining ecosystems and services.

- Enabling, where appropriate, alternative livelihoods and reducing socio-economic impacts.

What are the appropriate criteria for judging when mine closure, reclamation (rehabilitation) and postmining have been successful in achieving these, so responsibility can be relinquished by a mining company? This is a continuing problem for the mining industry and regulators. It also seems to be a very difficult one to nail down.

There are many guidelines and frameworks for mine closure and reclamation, and many case studies of success (and failures as well). However, the great majority of these are based on processes - methods and procedures, techniques and recipes - the 'means' rather than the 'ends', which are outcomes such as future use, performance and function.

Often success is judged in the very short term (say less than three years), and sometimes success always seems elusive and a long way off. Success is also judged post-facto, with hindsight, based on 'does it look good, or is it at least an improvement', rather than 'has it met our specific objectives'? Criteria, where they are set, tend to be considered from a single aspect or narrow perspective, such as ecological conditions. The author does not have any answers for this, other than to suggest that enlightenment and better longterm objectives and criteria will bring about improvements.

In contrast, there are many examples of sites where the absence of any closure, reclamation or regeneration success, or even attempts at it, has eventually given rise to valued industrial and cultural heritage, combined with high recreational value, many years later. A good example of this is the extensive UNESCO World Heritage Site: Cornwall and West Devon Mining Landscape, designated in 2006, which covers nearly 20,000 ha of land extensively mined for copper, tin and other base metals in the nineteenth century (UNESCO, 2006). This does not mean, of course, that it is acceptable to just ignore closure and rehabilitation of mines in order to generate historical and cultural capital for future generations! But what it does mean is that there can be a balance between different interests; we do not necessarily have to expunge all record of our activities, and some clouds have silver linings.

When it began to be taken seriously, from the 1970s, mine closure and reclamation was (and still is) based on a combination of technical or physical (engineering, construction, management) activities and biological activities (soils, vegetation).

One of the earliest guidelines for mine closure and reclamation, the Ontario Guidelines (Ontario Ministry of Northern Development and Mines, 1991), recognised that geochemical conditions were also important and identified three objectives to achieve: physical stability, chemical stability and land use stability. More recently, it is generally recognised that community and social closure is just as important, though the process and scope is very different and may well extend beyond the mine site itself.

Success or completion criteria are, or should be, used in a number of ways, each of which leads to a different idea of what success actually means, depending on the objective:

- Judging an award or industry accolade, considered to represent an exemplary example of good practice - unfortunately these are often based on short-term results and sometimes subjective criteria by a panel of judges. 
- Regulator sign-off and certification that a regulatory condition (e.g., to a licence or permit) has been satisfied - regulators rarely have adequate resources for a full audit or objective assessment, and often criteria are vague or non-specific.

- Mining company relinquishment of a licence or permit, or condition of a mining lease or contract, relieving them of continuing financial responsibility for the site - this is often linked to other responsibilities for safety, inspection of tips and underground workings, etc.

- Mining company internal discharge of responsibility or policy commitments for a site (which may exist without, or in the absence of, any legal or contractual responsibility), linked to corporate social responsibility or sustainability reporting and to stated environmental and stakeholder policies.

- Release of funding from a closure or reclamation budget, bond or financial instrument.

- Handover of a site to a post-mining owner or organisation with a long-term interest in a new land use.

- Discharge of a mine closure fund or financial instrument, enabling the residue to be dispersed and any management organisation or body to be wound up.

\section{Success criteria in the context of wider mine planning and the 'life of mine'}

At what stages during the life of a mine should success criteria be defined? As with most other aspects of mining, the earlier the better.

- Pre-mining planning and permitting, as part of an environmental and social impact assessment and framework Mine Closure and Reclamation Plan. This will set the closure and rehabilitation objectives to enable early identification of closure and mine planning requirements (particularly design for closure), proper financial provision to be included in the project economic assessment and full assessment of long-term environmental and social impacts and risks. However, at this stage the closure specifics and criteria can only be broad-brush, sufficient for feasibility and planning purposes.

- Detailed life-of-mine planning and operational management - regular updates (usually on a fiveyear cycle, but sometimes shorter) of the Mine Closure and Reclamation Plan. This gives the opportunity to review and update the objectives. Each review should be progressively more detailed as closure time approaches and as the eventual condition of, and opportunities for, the site are more predictable, as criteria can become more specific. Progressive reclamation of postoperational or completed areas is preferred, so very specific criteria would be applied to these areas early on.

- During detailed planning and implementation of the closure and decommissioning process - this is where most resources are expended and short-term criteria for matters such as decontamination, landform, soil placement and community development will be critical and should be very specific. This is also the time to confirm the objectives.

- During active care and monitoring (usually 5-10 years), criteria will enable adjustments to be made and management regimes to be adapted.

- Long-term passive care and monitoring, where the appropriate long-term criteria will determine whether success has or is likely to be achieved; this will involve both the mining company (or residual body managing the reclamation) and the new owner or administrative body.

- Ultimate condition and sign-off, with full relinquishment and transfer of responsibility, once success criteria have been achieved. 
The circumstances may also affect the choice and quantification of success criteria: whether they are for planned closure and progressive reclamation, or unplanned forced closure (rapidly changing economic or unexpected geological conditions) or when dealing with abandoned legacy sites.

\section{$3 \quad$ Setting objectives and criteria}

Good criteria will consist of two parts:

- Objectives - high-level and clear intentions, outcome or endpoint related to use, function, condition, economic status or community benefit to be achieved.

- Specific criteria and parameters used to measure progress towards achieving the objectives, when or whether these have been achieved or when adjustments need to be made.

Objectives could be general or corporate or be very site-specific and relevant to a particular situation and circumstances; there can be no standard set of criteria or one-size-fits-all. Objectives or criteria can be based on or set against:

- The pre-existing or baseline condition.

- A new condition or beneficial use or economic status.

- An alternative or reference site or condition nearby.

The objectives will also be influenced by the starting point - planned closure, unplanned/forced closure or rehabilitation of an abandoned site - and by the financial or skill resources thus available.

Closure and regeneration objectives will also be set according to:

- Corporate policies and standards, often influenced by international expectations and guidelines.

- Legal, regulatory and licence obligations and standards, including lenders' requirements, applicable to a project.

- Local and regional opportunities, needs and demands.

- Technical and human resources available.

- Available funding and other investment.

- Physical and chemical obstacles and constraints.

- Cultural, climatic and biotic factors influencing the site's potential.

Objectives for site use and the community are often considered as soft (vegetated) or hard (developed) uses, as summarised in Table 1. Note that these objectives are very generalised; in practice, more-specific objectives would be applied. These objectives are not mutually exclusive, and most sites will encompass a combination of overlapping or multiple objectives. The wider community and social objectives will not necessarily be site-focussed, but they may include wider employment and opportunities for alternative livelihoods. 


\section{Table 1 Relationship between site use objectives and relevant criteria}

\begin{tabular}{|c|c|c|}
\hline \multicolumn{2}{|r|}{ Site Use Objective } & \multirow{2}{*}{$\begin{array}{l}\text { Criteria (Indicators) For Success } \\
\text { Land use capability, productivity, fertility, } \\
\text { value of services; species composition }\end{array}$} \\
\hline Soft & $\begin{array}{l}\text { Productive (e.g., cropping, ecosystem } \\
\text { services) }\end{array}$ & \\
\hline & $\begin{array}{l}\text { Biodiversity, recreation (natural and } \\
\text { semi-natural ecosystems) }\end{array}$ & $\begin{array}{l}\text { Species diversity, habitat; plant } \\
\text { community type, presence of indicator } \\
\text { species }\end{array}$ \\
\hline & $\begin{array}{l}\text { Landscape (visual), soil protection, } \\
\text { bioengineering }\end{array}$ & $\begin{array}{l}\text { Land cover; erosion risk, specific species } \\
\text { thriving }\end{array}$ \\
\hline Hard & Economic (commercial, industrial) & $\begin{array}{l}\text { Development potential, infrastructure, } \\
\text { land value }\end{array}$ \\
\hline & Amenity, recreational & Access, infrastructure; use \\
\hline \multicolumn{2}{|c|}{ Community and social cohesion } & $\begin{array}{l}\text { Employment, economic indicators, } \\
\text { demographic changes }\end{array}$ \\
\hline
\end{tabular}

The recent interest in the concept of natural capital and particularly ecosystem services, as a way of expressing the tangible value of intangibles such as biodiversity and recreational value, provides a further possible set of indicators and criteria by which to measure success. However, quantifying the value of ecosystem services is still the subject of much research, and there are few well developed or accepted metrics.

Criteria, like all good goals and objectives, must be SMART - specific, measurable, achievable, relevant and time-bound. 'Measureable' can be by quantitative or qualitative means, or a combination of both, and involve some objective process (audit, monitoring). Approaches include:

- Visual inspection against pre-defined conditions and descriptors (parameters), which must be objective and repeatable and which can be semi-quantitative (e.g., subjective scales).

- Sampling, analysis and other direct data collection for physical, chemical, biological, ecological and economic metrics.

- Remote sensing and other mapping, geospatial and condition indicators.

- Specific measureable primary indicators, such as yields, productivity, values, incomes, stocking rates, demographics, etc.

- Secondary indicators based on other measurables, such as land use capability, soil erosion risk, ecosystem services, GDP.

There is likelihood that the criteria are later treated as targets, to be achieved. Targets can be a valuable tool, provided that they are reviewed and revised as more information becomes available. Good closure planning and implementation should involve adaptive management, enabling the success criteria to evolve through the mine life cycle and remain relevant to the ultimate objectives.

Unfortunately there are examples from other situations of the down side of reliance on targets, often because they have not been thought through or have been set with little understanding of the wider picture. It is human nature to manage a process towards meeting the targets set, and to tick the box as quickly and cheaply as possible. However, this is often at the expense of a long-term or sustainable objective. So criteria should be set with care, with a clear view of the objectives and intentions. 
Risk assessment: the risk that the success criteria will not be met will need to take account of the risk of failure or shortcomings due a range of factors:

- Unpredicted conditions, events or circumstances.

- The design or implementation is inadequate or has shortcomings.

- Exceptional or extreme conditions (flooding, storms) outside of predicted or design standards.

- Poor implementation, faulty workmanship, lack of inspection.

- Inadequate provision for aftercare, follow through, monitoring or long-term management.

These factors can all be the result of funding, expertise (incompetence, naivety) or management, or most likely a combination of all three.

\section{$4 \quad$ Examples of success criteria}

The Appendix to this paper provides examples of the range and types of criteria that might be selected and applied. These are grouped under seven headings: ecological, geochemical, engineering/geotechnical, hydrological, economic, cultural and - last - social and community. The particular selection and application of any set of these criteria will be site-specific and will also reflect the importance of the specific aspect in representing the objective, condition and end use.

This is not intended as a review of criteria used elsewhere, and it is certainly not comprehensive. It is accepted that the framework would benefit greatly from specific examples, looking at how they are used, difficulties, successes and failures. However, that is for another day. The purpose here is to raise questions and suggest an approach as a framework for discussion for the industry, regulators and regeneration/ rehabilitation specialists to take forward.

\section{References}

Ontario Ministry of Northern Development and Mines (1991) Rehabilitation of Mines - Guidelines for Proponents, Sudbury, Ontario.

UNESCO (2006) http://whc.unesco.org/en/list/1215. 


\section{Appendix}

A framework for mine closure and reclamation success criteria

\begin{tabular}{|c|c|c|}
\hline Criteria Type & Criteria Group & Factors and Indicators for Criteria \\
\hline \multicolumn{3}{|l|}{ Ecological } \\
\hline \multirow[t]{7}{*}{ Vegetation } & Ground cover & $\begin{array}{l}\text { Density and \% cover; layers \& canopy structure (herbaceous, } \\
\text { shrub and tree) }\end{array}$ \\
\hline & \multirow[t]{2}{*}{ Species present } & $\begin{array}{l}\text { Species presence/absence; cover abundance using Domin or } \\
\text { similar scale. Potential to use multivariate analysis of } \\
\text { community type and relate to recognised community } \\
\text { classifications }\end{array}$ \\
\hline & & Presence of alien or invasive species \\
\hline & \multirow[t]{2}{*}{ Biodiversity } & $\begin{array}{l}\text { Indices such as diversity; biodiversity value based on diversity, } \\
\text { naturalness, rarity/scarcity, against recognised classifications; } \\
\text { can be referenced to modified, natural or critical habitat (IFC } \\
\text { PS6) }\end{array}$ \\
\hline & & Ability to support vulnerable or protected species \\
\hline & $\begin{array}{l}\text { Land use, } \\
\text { productivity }\end{array}$ & $\begin{array}{l}\text { Yields, productivity of biomass or crop; stocking densities } \\
\text { sustained (and sustainable, not short-term achievement) }\end{array}$ \\
\hline & Fragility & Vulnerability to change or damage, climate, herbivores \\
\hline \multicolumn{2}{|c|}{$\begin{array}{l}\text { Land capability (potential \& } \\
\text { flexibility for future use) }\end{array}$} & $\begin{array}{l}\text { Established Land Use Capability classifications, based on } \\
\text { slope, soil, drainage, exposure, bioclimate, such as FAO and } \\
\text { UK LCC methodology }\end{array}$ \\
\hline \multirow{5}{*}{$\begin{array}{l}\text { Soil-forming } \\
\text { material }\end{array}$} & Profile & Depth and nature (layers) of profile, significant to $1 \mathrm{~m}$ depth \\
\hline & Type & $\begin{array}{l}\text { Soil type, usually based on particle sizes, density and porosity; } \\
\text { use of salvaged topsoil or alternative soil forming material }\end{array}$ \\
\hline & Fertility & $\begin{array}{l}\text { Organic matter, Total-N, P \& K contents with reference to } \\
\text { agricultural use indices }\end{array}$ \\
\hline & Available water & $\begin{array}{l}\text { Available water capacity and potential profile-available water, } \\
\text { according to standard methodology, based on particle size } \\
\text { distribution, density and depth }\end{array}$ \\
\hline & Erosion risk & $\begin{array}{l}\text { Erosion risk according to standard methodology (Universal } \\
\text { Soil Loss Equation); erodibility of soil and erosivity of wind } \\
\text { and water }\end{array}$ \\
\hline \multicolumn{3}{|l|}{ Geochemical } \\
\hline \multicolumn{2}{|c|}{ Ground contamination } & $\begin{array}{l}\text { Standard contaminated land and cleanup standards } \\
\text { applicable to a range of contaminants, with criteria based on } \\
\text { risk and constraints to future users }\end{array}$ \\
\hline \multicolumn{2}{|c|}{ Acid rock drainage } & $\begin{array}{l}\text { Sulphide-S (pyrite) content - standard methodology for acid- } \\
\text { base accounting and estimation of net-acid-generating } \\
\text { potential - static and dynamic testing; apply criteria to waste } \\
\text { rock, tailings, etc. within } 2 \mathrm{~m} \text { of final surface or soil-forming } \\
\text { material }\end{array}$ \\
\hline
\end{tabular}




\begin{tabular}{|c|c|c|}
\hline Criteria Type & Criteria Group & Factors and Indicators for Criteria \\
\hline \multirow{3}{*}{\multicolumn{2}{|c|}{ Leaching/release of contaminants }} & \\
\hline & & $\begin{array}{l}\text { potential plant uptake of contaminants such as heavy metals } \\
\text { and salts }\end{array}$ \\
\hline & & $\begin{array}{l}\text { Monitor ultimate surface water discharge and groundwater } \\
\text { quality, with reference to standards }\end{array}$ \\
\hline \multicolumn{3}{|c|}{ Engineering/geotechnical } \\
\hline \multirow[t]{2}{*}{ Structures } & Removal & $\begin{array}{l}\text { Removal and reuse/recycling of structures, buildings, } \\
\text { infrastructure in accordance with engineering specification, to } \\
\text { ground level or }+/ \text { - foundations }\end{array}$ \\
\hline & Infrastructure & $\begin{array}{l}\text { Retention, refurbishment or removal of power, water, gas, } \\
\text { access, etc. infrastructure, depending on potential for future } \\
\text { use }\end{array}$ \\
\hline \multirow[t]{3}{*}{ Landform } & Earthmoving & $\begin{array}{l}\text { Cut and fill to achieve new landform; slopes and gradients to } \\
\text { suit new landform }\end{array}$ \\
\hline & Drainage & $\begin{array}{l}\text { Adequate drainage to remove excess water to suitable } \\
\text { outfall, designed according to normal engineering standards }\end{array}$ \\
\hline & $\begin{array}{l}\text { Ground } \\
\text { conditions }\end{array}$ & Bearing capacity appropriate to future use \\
\hline \multirow[t]{3}{*}{ Stability } & Slopes & Factor of safety in accordance with engineering practice \\
\hline & Rock faces & $\begin{array}{l}\text { Condition suitable for future use and safety of access for } \\
\text { people, livestock }\end{array}$ \\
\hline & Subsidence & $\begin{array}{l}\text { Settlement criteria suitable for future use and risks to surface } \\
\text { infrastructure }\end{array}$ \\
\hline \multicolumn{3}{|l|}{ Hydrological } \\
\hline \multicolumn{2}{|c|}{ Open pits and ponds } & $\begin{array}{l}\text { Fluctuations of water level within specified limits, relevant to } \\
\text { use }\end{array}$ \\
\hline \multirow[t]{2}{*}{ Drainage } & $\begin{array}{l}\text { Surface water } \\
\text { management }\end{array}$ & $\begin{array}{l}\text { Separation of clean and potentially contaminated } \\
\text { catchments; performance of attenuation lagoons }\end{array}$ \\
\hline & Flooding & $\begin{array}{l}\text { Design for high rainfall and streamflow of specified return } \\
\text { period (1:500 years?) }\end{array}$ \\
\hline \multirow[t]{3}{*}{ Water quality } & Groundwater & $\begin{array}{l}\text { Extent of dispersion plume (boreholes up and downstream } \\
\text { for monitoring); reference to predictive modelling }\end{array}$ \\
\hline & \multirow{2}{*}{$\begin{array}{l}\text { Surface water } \\
\text { discharge }\end{array}$} & Discharge limits at outfalls \\
\hline & & $\begin{array}{l}\text { Passive treatment and attenuation ponds - hydraulic and } \\
\text { biological integrity and performance }\end{array}$ \\
\hline $\begin{array}{l}\text { TMF and } \\
\text { waste dumps }\end{array}$ & Water balance & $\begin{array}{l}\text { Performance of cover to limit infiltration or upward capillary } \\
\text { flows; quality \& quantity of basal underdrainage and surface } \\
\text { drainage }\end{array}$ \\
\hline Groundwater & Rebound & Controlled rate of rebound; water treatment parameters \\
\hline
\end{tabular}




\begin{tabular}{|c|c|c|}
\hline Criteria Type & Criteria Group & Factors and Indicators for Criteria \\
\hline \multicolumn{3}{|l|}{ Economic } \\
\hline \multirow[t]{2}{*}{$\begin{array}{l}\text { Land } \\
\text { utilisation }\end{array}$} & Land values & $\begin{array}{l}\text { A long-term criterion, based on conventional market } \\
\text { valuation }\end{array}$ \\
\hline & Land use & $\begin{array}{l}\text { Value and condition suitable for agriculture, forestry or } \\
\text { horticulture, energy crops, or commercial/ industrial use }\end{array}$ \\
\hline Infrastructure & $\begin{array}{l}\text { Access, power, } \\
\text { etc. }\end{array}$ & $\begin{array}{l}\text { Define requirements to support the desired land utilisation; } \\
\text { include mining infrastructure that has a continuing use }\end{array}$ \\
\hline \multicolumn{3}{|l|}{ Cultural } \\
\hline \multirow[t]{2}{*}{ Archaeological } & $\begin{array}{l}\text { Mining historical } \\
\text { and cultural value }\end{array}$ & $\begin{array}{l}\text { Retention of artefacts or features to represent the site's } \\
\text { period of use for mineral extraction }\end{array}$ \\
\hline & $\begin{array}{l}\text { Other historical } \\
\text { value }\end{array}$ & $\begin{array}{l}\text { Retention or preservation of previous historical value of the } \\
\text { site }\end{array}$ \\
\hline \multirow[t]{2}{*}{ Landscape } & Visual intrusion & $\begin{array}{l}\text { Visibility within and contrast to the surrounding landscape - } \\
\text { difficult to quantify with criteria as this is mostly subjective }\end{array}$ \\
\hline & $\begin{array}{l}\text { Landscape } \\
\text { quality }\end{array}$ & $\begin{array}{l}\text { Landforms and land cover that are congruent with the } \\
\text { landscape within which the site fits }\end{array}$ \\
\hline \multicolumn{3}{|c|}{ Social and community } \\
\hline \multirow[t]{2}{*}{ Safety } & Public & Hazard removal and management of access for proposed use \\
\hline & Future occupiers & $\begin{array}{l}\text { Hazard removal and management of future environmental, } \\
\text { safety and health risks }\end{array}$ \\
\hline Accessibility & & $\begin{array}{l}\text { Managed access points to the site and accessibility within the } \\
\text { site, including crossings }\end{array}$ \\
\hline \multirow[t]{3}{*}{$\begin{array}{l}\text { Employment, } \\
\text { livelihoods }\end{array}$} & Skills \& support & $\begin{array}{l}\text { Provision of training and skills transfer, entrepreneurial } \\
\text { support for alternative livelihoods and enterprises }\end{array}$ \\
\hline & Finance & $\begin{array}{l}\text { Availability of credit and financial support for new } \\
\text { enterprises; markets }\end{array}$ \\
\hline & Employment & Employment opportunities \\
\hline \multirow[t]{2}{*}{ Demographics } & & $\begin{array}{l}\text { Inward and outward migration - maintaining the correct } \\
\text { balance of population and age structure }\end{array}$ \\
\hline & & Return to original state or adjust to new state? \\
\hline
\end{tabular}


